\title{
UV Spectrophotometric method for quantitative determination of Bilastine using experimental design for robustness
}

\author{
Andressa Tassinari da Silva ${ }^{\text {a }}$; Gabriela Rossi Brabo ${ }^{\text {a }}$, Isadora Dias Marques ${ }^{\text {a, b}}$; Lisiane Bajerski ${ }^{\text {a }}$; \\ Marcelo Donadel Malesuik ${ }^{\mathrm{a}, \mathrm{b}}$; Clésio Soldateli Paim ${ }^{\mathrm{a}, \mathrm{b}, *}$ \\ ${ }^{a}$ Laboratório de Pesquisa em Desenvolvimento e Controle de Qualidade; Curso de Farmácia; Universidade Federal do \\ Pampa (UNIPAMPA - Campus Uruguaiana-RS), BR 472 - Km 585, CEP 97500-970, Uruguaiana (RS), Brasil. \\ b Programa de Pós-Graduação em Ciências Farmacêuticas, Curso de Farmácia, Universidade Federal do Pampa \\ (UNIPAMPA - Campus Uruguaiana-RS), BR 472 - Km 585, CEP 97500-970, Uruguaiana (RS), Brasil.
}

Corresponding author e-mail: clesiopaim@unipampa.edu.br

Bilastine is a novel nonsedative H1-receptor antagonist, which may be used for the symptomatic treatment of chronic idiopathic urticaria (CU). This study describes the validation of an UV spectrophotometric method for quantitative determination of bilastine in tablets using $0.1 \mathrm{~mol} \mathrm{~L}^{-1} \mathrm{HCl}$ as solvent. The method was specific, linear, precise, exact and robust at $210 \mathrm{~nm}$, confirming that the method is fast and useful to the routine quality control of bilastine in tablets. The validate method was compared to liquid chromatography (HPLC), which was previously developed and validated to the same drug, and no significative difference between the methods using Student's t test was found to bilastine quantitation.

Keywords: bilastine; experimental design, UV spectrophotometric method.

\section{Introduction}

Bilastine (Figure 1) is a novel nonsedative H1-receptor antagonist, which may be used for the symptomatic treatment of chronic idiopathic urticaria and allergic rhinoconjunctivitis (1).

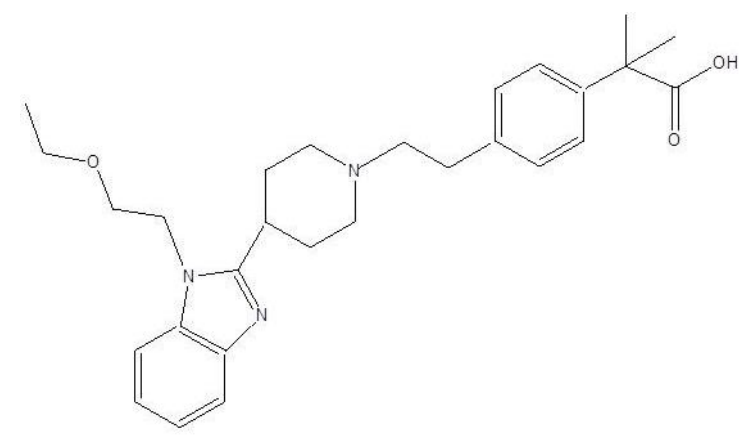

Figure 1 Chemical structure of bilastine.

Pharmacological studies have shown that the drug is highly selective for the $\mathrm{H} 1$ receptor in both in vivo and in vitro studies, and with no apparent affinity for other receptors. The absorption of bilastine is fast, linear and doseproportional; it appears to be safe and well tolerated at all doses levels in healthy population (2).

Although there are some papers describing the determination of bilastine in pharmacokinetic studies by LC-fluorescence detection and LC-MS-MS (3, 4) and by hydrophilic interaction liquid chromatographic method (HILIC) (5), there are no studies describing quantification methods by UV spectrophotometry. Then the main objective of this study was to develop a simple, fast and low cost UV spectrophotometry method, without extraction process, derivatization process, and evaporation step, providing decrease in time and error in the quantitative determination of bilastine in tablets.

The method described in this study was validated through the evaluation of the following analytical parameters: specificity, linearity, precision (repeatability and intermediate precision), accuracy and robustness $(6,7)$. Experimental design was used to evaluate method robustness (8). Besides, the 
statistical comparison of the precision results with those obtained from the HPLC (previously validated by the same research group) was presented to show the suitability of the developed method.

\section{Experimental}

\section{Reagents and Chemicals}

Bilastine chemical reference standard (CRS) (99.7\%) was acquired from TRC (Toronto, Ontario, Canada). Alektos ${ }^{\circledR}$ (Takeda, São Paulo, Brazil), composed of a $20 \mathrm{mg}$ bilastine, was purchased in the market. The excipients contained in the dosage form (microcrystalline cellulose, sodium starch glycolate, magnesium stearate and colloidal silicon dioxide) were all pharmaceutical grades and were acquired from different suppliers. All chemicals and solvents used were of analytical grade. Methanol was purchased from Avantor ${ }^{\circledR}$ (J.T.BAKER, Center Valley, PA, USA) and Neon ${ }^{\circledR}$ (Suzano, SP, Brazil). Acetonitrile HPLC grade was purchased from Avantor ${ }^{\circledR}$ (J.T.BAKER, Center Valley, PA, USA). Purified water was prepared using Milli-Q Plus ${ }^{\circledR}$ (Millipore, Bedford, USA).

\section{Instrumentation and Conditions}

Spectral and absorbance measurements were performed with an UV-Vis Perkin-Elmer, model Lambda 35 using $10 \mathrm{~mm}$ quartz cells and detection at $210 \mathrm{~nm}$.

A Shimadzu Prominence ${ }^{\circledR} \quad$ liquid chromatograph (Kyoto, Japan) LC Solution V. 1.24 SP1 manager system software was used. The chromatographic separation was performed in a Shim-pack ${ }^{\circledR}$ RP-18 column (150 x 4.6 mm I.D., 5 m, Shimadzu, Kyoto, Japan). The mobile phase comprising a mixture of $0.3 \%$ triethylamine ( $\mathrm{pH}$ adjusted to 6.0 with $20 \%$ formic acid) and acetonitrile $(55: 45, v / v)$ at a flow-rate of $1.0 \mathrm{~mL} \mathrm{~min}^{-1}$ with isocratic elution at $25^{\circ} \mathrm{C}$. The injection volume was $20 \mu \mathrm{L}$ for both reference substance and drug product solutions and the run time was 5 min. Bilastine was determined by UV detection at $207 \mathrm{~nm}$ using photodiode-array.

\section{Preparation of RS and sample solutions}

Bilastine CRS was accurately weighed and dissolved in a $100 \mathrm{~mL}$ volumetric flask with 0.1 mol L-1 $\mathrm{HCl}$ to produce a concentration of 100.0 $\mu \mathrm{g} \mathrm{mL}^{-1}$. This solution was diluted appropriately in the same diluent to yield a final concentration of $10.0 \mu \mathrm{g} \mathrm{mL}^{-1}$. To prepare a sample solution, twenty tablets of Alektos ${ }^{\circledR}$ were weighed and finely powdered. A quantity equivalent to $5.0 \mathrm{mg}$ of the bilastine was transferred into a $50 \mathrm{~mL}$ volumetric flask with $30 \mathrm{~mL}$ of $0.1 \mathrm{~mol} \mathrm{~L}^{-1} \mathrm{HCl}$ and kept in an ultrasonic bath for $30 \mathrm{~min}$. The volume was completed with the same diluent, filtered and an aliquot of this solution was volumetrically diluted to yield a final concentration of $10.0 \mu \mathrm{g}$ $\mathrm{mL}^{-1}$. The stability of bilastine CRS and sample solutions in $0.1 \mathrm{~mol} \mathrm{~L}^{-1} \mathrm{HCl}$ was evaluated at room temperature $\left(23 \pm 1^{\circ} \mathrm{C}\right)$ during $24 \mathrm{~h}$ using the HPLC method. The stability of these solutions was verified by observing any change in the chromatographic pattern and in the decrease of the response of the peak (area), which can indicate the degradation of the solutions.

\section{Method validation}

Different solvents were investigated to develop a suitable UV spectrophotometric method for the analysis of bilastine in tablets. For selection of solvent the criteria employed was the easiness of sample preparation, solubility and stability of the drug, cost of solvent, toxicity and applicability of the method.

The evaluation of the method specificity was performed by preparing a placebo containing the same excipients of the commercial product. A quantity of excipients contained in the equivalent to $5.0 \mathrm{mg}$ of the bilastine was transferred into a $50 \mathrm{~mL}$ volumetric flask with $30 \mathrm{~mL}$ of $0.1 \mathrm{~mol} \mathrm{~L}^{-1} \mathrm{HCl}$ and kept in an ultrasonic bath for $30 \mathrm{~min}$. The volume was completed with the same diluent, filtered and $1.0 \mathrm{~mL}$ of this solution was transferred into a $10 \mathrm{~mL}$ volumetric flask using $0.1 \mathrm{~mol} \mathrm{~L}^{-1} \mathrm{HCl}$. 
Three calibration curves were prepared with six concentrations of bilastine CRS at 210 $\mathrm{nm}\left(3.0,4.0,5.0,10.0,15.0\right.$ and $\left.20.0 \mu \mathrm{g} \mathrm{mL}^{-1}\right)$ to evaluate the linearity and for each concentration the solutions were prepared in triplicate. The obtained absorbances were plotted against the respective concentrations of drug to obtain the analytical curves. The calculation of the regression line was employed by the method of least squares and the curves were validated by means of the analysis of variance (ANOVA).

The determination of precision was done through six sample solutions at the same concentrations $\left(10.0 \mu \mathrm{g} \mathrm{mL}^{-1}\right)$ under the same experimental conditions in the same day for intra-day precision (repeatability) and on three different days for inter-day precision (intermediate precision). The relative standard deviations (RSD) were determined.

Accuracy was calculated as percentage recovery by adding known amounts of bilastine CRS to synthetic mixtures of the formulation excipients. The analyses were done in three replicates in each concentration $(3.0,10.0$, and $\left.20.0 \mu \mathrm{g} \mathrm{mL}^{-1}\right)$.

The robustness tests using experimental design in the bilastine assay provided an effective approach as part of the method validation. Robustness testing was performed in order to evaluate the susceptibility of measurements due to deliberate variations in analytical conditions. The factors were examined in an experimental design of 8 experiments, which was selected as a function of the number of factors to investigate (8). This designs applied, so-called two-level screening designs, allows screening a relatively large number of factors in a relatively small number of experiments.

The factors and the levels investigated in robustness evaluation are summarized in Table 1. The construction of the experimental designs with 8 experiments was performed in accordance to Plackett-Burman described in Heyden and collaborators (8). After determination of the number of real factors to be examined, the remaining columns in the design were defined as dummy factors, which is an imaginary factor that has no physical meaning. A half-normal probability plot for the effects in combination with the dummy factors was used to estimate the error and identify significant effects.

\begin{tabular}{lccc} 
Table 1 Factors and levels investigated in the robustness test. \\
\hline Factors & Nominal & Level (-1) & Level (+1) \\
\hline Solvent brand & J.T.Baker $^{\circledR}$ & Neon $^{\circledR}$ & J.T.Baker $^{\circledR}$ \\
$\begin{array}{l}\text { Time of Shaking } \\
\text { ultrasonic bath) (min.) }\end{array}$ & 30 & 28 & 32 \\
Wavelength (nm) & 210 & 208 & 212 \\
\hline
\end{tabular}

For each factor its resulting effect was calculated according to the Equation 1:

$$
E_{x}=\frac{\sum Y(+)}{N / 2}-\frac{\sum Y(-)}{N / 2} \quad \text { (Equation 1) }
$$

Where: $E_{X}$ is the effect of $X$ on response $Y$ (bilastine concentration); $\sum Y(+)$ and $\sum Y(-)$ are the sums of the responses where $X$ is at the extreme levels (+) and (-), respectively, and $N$ is the number of experiments of the design.

The effect of the estimate experimental error $(\mathrm{SE})_{\mathrm{e}}$ allows concluding what is significant from dummy factors (Equation 2). This value was used to perform the statistical test.

$$
(S E)_{e}=\sqrt{\frac{\sum E_{\text {dummy }}^{2}}{n_{\text {error }}}} \text { (Equation 2) }
$$

Where: $\sum E^{2}$ error is the sum of squares of the $n_{\text {error }}$ dummy.

The statistical interpretation provides to the user a numerical limit value that allows defining what is significant and what is not. This limit value to identify statistically significant effects is usually derived from the $t$ test statistic, in accordance to the Equation 3: 


$$
t=\frac{\left|E_{x}\right|}{(S E)_{e}} \text { (Equation 3) }
$$

An effect is considered significant at a given $\alpha$ level if $t$ calculated $>t$ critical (8).

\section{Methods comparison}

In order to compare the developed UV spectrophotometry method at $210 \mathrm{~nm}$ with well characterized procedure (HPLC method previously validated), the precision results of these methods were statistically analyzed using Student's t test, which indicates if there is significant difference between the methods at $5 \%$ significant level.

\section{Results and Discussion}

The UV-VIS method is very used in the quality control of pharmaceutical products due to the potential of the great majority of the drugs of absorbing energy in these wavelengths. The development of a simple, rapid, sensitive, and accurate UV spectrophotometric method for the routine quantitative determination of samples reduces unnecessary tedious sample preparations and the cost of analysis (9).

Considering the solubility and stability, the following solvents were used as diluent of the bilastine in the CRS and the sample solutions: methanol and $0.1 \mathrm{~mol} \mathrm{~L}^{-1} \mathrm{HCl}$. The stability of bilastine in acid solution was evaluated to verify if any spontaneous degradation occurs when the samples were prepared. The studies performed by HPLC method showed the stability of the drug in acid solution by $24 \mathrm{~h}$. Besides that, the $0.1 \mathrm{~mol} \mathrm{~L}^{-1} \mathrm{HCl}$ is considered less toxic than methanol. Then the utilization of this solvent was evaluated to perform the spectrophotometric method validation (Figure 2).
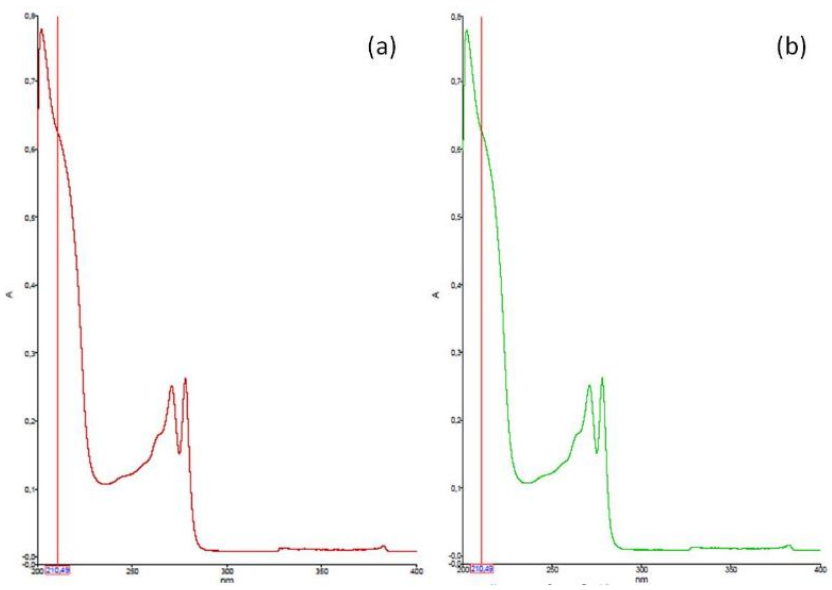

Figure 2 UV-absorption spectra of $10.0 \mu \mathrm{g} \mathrm{mL}^{-1}$ concentration of bilastine in tablets (a) and bilastine CRS solutions (b) in $0.1 \mathrm{~mol} \mathrm{~L}^{-1} \mathrm{HCl}$.

The specificity test demonstrated that there was not interference of the excipients in the drug determination at $210 \mathrm{~nm}$ using $0.1 \mathrm{~mol} \mathrm{~L}^{-}$

${ }^{1} \mathrm{HCl}$ as solvent.

Linearity was observed over the concentrations range of 3.0 to $30.0 \mu \mathrm{g} \mathrm{mL}^{-1}$ at $210 \mathrm{~nm}$ with significantly high value of correlation coefficient $(\mathrm{r}=0.9998)$. The validity of the assay was verified by means of ANOVA and according to it, there are linear regression and there are not deviation from linearity $(\alpha=$ 0.05 , Table 2).

\begin{tabular}{|c|c|}
\hline Regression analysis & $\lambda 210 \mathrm{~nm}$ \\
\hline Linearity range $\left(\mu \mathrm{g} \mathrm{mL}^{-1}\right)$ & $3-20$ \\
\hline Slope & 0.0525 \\
\hline Intercept & -0.0042 \\
\hline Correlation coefficient (r) & 0.9998 \\
\hline Lack of fitting (critical F-value) ${ }^{\mathrm{a}}$ & $0.21(3.26)$ \\
\hline $\begin{array}{l}\text { Linear regression F-value (critica } \\
\text { value) }\end{array}$ & $6460.6(3.11)$ \\
\hline
\end{tabular}

The Student's $t$-test was performed to verify the significance of the experimental intercept in the regression equation. According to the results, it is not significantly different from the theoretical zero value with a significance level of $5 \%(p>0.05)$. 
The experimental values obtained for the determination of the analytical method precision (repeatability and intermediary precision) are presented in Table 3. The low relative standard deviations (RSD) obtained for the repeatability and intermediary precision showed the good precision of the analytical method.

Table 3 Repeatability values obtained for bilastine in tablets by UV spectrophotometry at $210 \mathrm{~nm}$.

\begin{tabular}{cccc}
\hline \multirow{3}{*}{ Sample (n) } & \multicolumn{3}{c}{ Repeatability } \\
\cline { 2 - 4 } & Day 1 & Day 2 & Day 3 \\
\hline 1 & 99.55 & 101.93 & 99.74 \\
3 & 101.26 & 100.32 & 99.11 \\
4 & 103.30 & 99.05 & 97.39 \\
5 & 103.48 & 101.95 & 99.27 \\
6 & 102.45 & 102.98 & 99.86 \\
\hline Mean (\%) & 102.03 & 103.78 & 100.25 \\
\hline RSD (\%) & 1.43 & 101.67 & 99.27 \\
\hline RSD (\%) & & 1.70 & \\
\hline Inter-day - Mean values \% (n=18) & \\
\hline Mean (\%) & & 100.99 & \\
\hline
\end{tabular}

The accuracy was calculated in relation of the percentage of recovery of the known added amount of bilastine CRS to the excipients solution. The accuracy of the method ranged from 99.53 to $100.54 \%$. These values showed the good accuracy of the purposed method.

The results of the robustness experiments are presented in Table 4. They are expressed in percentage of bilastine in the sample solution calculated using standard solution in the same experimental condition. The effects of the factors in analysis, the error estimated starting from the factors dummy and the value of $t$ calculated are also showed in Table 4. The analysis of the results of the robustness study demonstrated that the factors in analysis did not present significant effect on the quantitation of the drug, indicating the robustness of the UV spectrophotometric method in the analytical conditions.

Table 4 The selected Plackett-Burman design, results of the experiments and effects (Ex) of the factors.

\begin{tabular}{|c|c|c|c|c|c|c|c|c|}
\hline Esp & Sonic & $\lambda(\mathrm{mm})$ & Dexmy & Duxwy & Dearmy & Soltens & Dranny & $\begin{array}{c}\% \\
\text { blanting }\end{array}$ \\
\hline 1 & - & + & - & . & - & . & . & 100.00 \\
\hline 2 & . & + & + & + & . & + & . & 100.00 \\
\hline 3 & . & . & + & + & + & . & + & 97.94 \\
\hline 4 & + & . & - & + & + & + & - & 98.68 \\
\hline 5 & - & + & - & - & + & + & + & 101.03 \\
\hline 6 & - & . & - & . & . & * & * & 99.56 \\
\hline$?$ & + & + & . & + & . & . & + & 27.94 \\
\hline 8 & . & . & . & . & . & . & . & 101.47 \\
\hline E. & -1.08 & 0.33 & -0.40 & -1.87 & -0.33 & 0.48 & .0 .92 & \\
\hline (SE) & 1.075 & & & & & & & \\
\hline test & .0 .58 & 0.31 & & & & 0.44 & & \\
\hline $\sin$ & 2.933 & & & & & & & \\
\hline
\end{tabular}

The statistical comparison between the UV spectrophotometry at $210 \mathrm{~nm}$ and HPLC method was performed through Student's t test using the mean experimental values, obtained in the precision of the methods (Table 5). The test did not show statistical difference between the techniques $\left(\mathrm{t}_{\text {calc }}=0.0011\left\langle\mathrm{t}_{\text {crit }}=1.691, \mathrm{p}\right\rangle\right.$ $0.05)$, showing also the capacity of this developed method to quantify the drug bilastine in tablets with accuracy and precision.

Table 5 Statistical analysis between HPLC and UV methods.

\begin{tabular}{ccc}
\hline & HPLC assay (\%) & UV assay (\%) \\
\hline Mean (\%) (n=18) & 99.21 & 100.99 \\
\hline SD & 1.90 & 1.84 \\
\hline RSD & 1.91 & 1.82 \\
\hline Student's t test & & \\
& & \\
\hline T critical & $0.05)$ & \\
\hline
\end{tabular}

\section{Conclusions}

An HPLC-UV method was developed for determining the encapsulation efficiency of zidovudine in nanoparticles. This chromatographic method was considered 
simple and rapid, since the preparation of the samples did not involve complex and prolonged processes. Furthermore, the HPLC-UV method was validated in terms of selectivity, stability, linearity, limits of quantitation and detection, precision, accuracy and robustness. Finally, it provided unequivocal determination of the amount of zidovudine in nanoparticule formulation which may be applied to stability or quality control.

\section{Acknowledgements}

The authors wish to thank CNPq (Brazil) for the financial support (Project Universal CNPQ 457629/2014-2) and PDA 2017 UNIPAMPA (UNIVERSIDADE FEDERAL DO PAMPA - URUGUAIANA-RS, BRASIL).

\section{Conflits of Interest}

Nothing to declare.

\section{References}

1. Zuberbier T, Oanta A, Bogacka E, Medina I, Wesel F, Uhl P, et al. Comparison of the efficacy and safety of bilastine $20 \mathrm{mg} v \mathrm{~s}$ levocetirizine $5 \mathrm{mg}$ for the treatment of chronic idiopathic urticaria: a multi-centre, double-blind, randomized, placebocontrolled study. Allergy 2010;65(4):516528.

2. Scaglionte F. Safety profile of bilastine: 2nd generation $\mathrm{H} 1$-antihistamines. Eur Rev Med Pharmacol Sci. 2012;16(14):19992005.

3. Berrueta LA, Fernandez-Armentia M, Bakkali A, Gonzalo A, Lucero ML, Orjales A. Matrix solid-phase dispersion technique for the determination of a new antiallergic drug, bilastine, in rat faeces. J Chromatogr B 2001; 760:185-190.

4. Lasseter KC, Sologuren A, La Noce A, Dilzer SC. Evaluation of the single-dose pharmacokinetics of bilastine in subjects with various degrees of renal insufficiency. Clin Drug Investi 2013; 33:665-673.

5. Terzić J, Popović I, Stajić A, Tumpa A, Jancić-Stojanović B. Application of Analytical Quality by Design concept for bilastine and its degradation impurities determination by hydrophilic interactionliquid chromatographic method. J Pharm Biomed Anal 2016; 125:385-393.

6. ICH. Harmonised Tripartide Guideline: Validation of Analytical Procedure: Text and Methodology Q2 (R1), 2005. http://www.ich.org/LOB/media/MEDIA4 17.pdf, acessado em Abril de 2017.

7. The United States Pharmacopeia, $38^{\text {th }}$ ed., United States Pharmacopeial Convention: Rockville, 2015.

8. Heyden YV, Nijhuis A, SmeyersVerbeke, J, Vandeginste, BGM, Massart DL. Guidance for robustness/ruggedness tests in method validation. J Pharm Biomed Anal 2001;24:723-753.

9. Watson, GD. Pharmaceutical Analysis: A textbook for pharmacy students and pharmaceutical chemists, 2nd ed. Churchill Livingstone: London; 2005. 